\title{
Controlling in networking organisations - the concept and assumptions
}

Ph.D. Eng. Agnieszka Bieńkowska Wroclaw University of Technology

Ph.D. Eng Anna Zabłocka-Kluczka Wroclaw University of Technology

\section{Introduction}

Both management practitioners and theorists include controlling in the group of concepts of dynamic nature (compare e.g. Skrzyniarz 2002). What makes controlling dynamic is the fact that it is deeply rooted in practice and that this concept has always been connected with practice. As a result, controlling very quickly responds to changes taking place in the economic reality, thus, developing further new solutions which more and more perfectly improve management of an enterprise, which makes its existence more effectively secured.

What is one of the key tendencies in the contemporary economic practice is learning how to establish co-acting and cooperation among particular entities functioning in the economy. The opinion that this ability is of key importance for the creation of the conditions of improved competitiveness of particular enterprises is more and more common. This tendency is connected with the fact that the possibilities of accomplishing objectives of single organisations are more and more frequently limited because of such factors as resources of technical knowledge, financial means, market information or 
skilled managerial staff. In such cases a necessity arises to establish a network of cooperation, also referred to as networking organisations, networking enterprises or networking structures. A. Tubilewicz even expressed an opinion that "creation of new models of business organisations allowing for quick cooperation, coordination and establishment of relations beyond the organisational borders characterised by the construction of a network of enterprises and processes connecting suppliers of materials and services, designers, distributors, infrastructural partners, sale partners, R\&D centres and IT centres as well as clients is an expression of the phenomena that unprecedentedly change the contemporary business" (Tubielewicz 2013, p. 387).

In view of the above statements and in the context of ascertaining the dynamic nature of controlling it is not surprising that the concept of controlling dedicated to networking organisations was formulated (networking controlling), constituting a response to (inter alia) the need to coordinate activities in the scope of management of relations among entities cooperating within a network. The presented type of controlling is an original concept, which is why it constitutes a subject of scientific discourse to a small extent only. The literature does not present the solutions of networking controlling, either. Thus, the purpose of this paper is to present the issue of networking controlling and to indicate solutions aimed to support processes occurring among entities composing a network of cooperation, resulting from the pre-defined purpose of the cooperation.

\section{A networking organisation as the expression of cooperation among entities}

Despite the fact that the issue of cooperation is more and more popular both as regards theory and practice of management, the very concept of the network of cooperation is a category that has not been thoroughly researched or structured. The literature provides different terms for description of the network, such as networking organisation, networking enterprise, networking structures, networks. "Enterprise or enterprises organised in the form of a network constitute a very vast area and the strive to create their typology comes across barriers of liquidity of forms and discontinuousness contained in the very concept of the network" (Strategor 1995, p. 39).

A networking organisation is understood as a system of inter-organisational relations allowing the organisations connected with one another to implement a certain joint strategic intention, which increases their common efficiency (Góra 2008, p. 13). What characterises networks of organisations is considerable interdependence and internal relationships which are relatively strong but at the 
same time flexible and open (Tubielewicz 2013, p. 387). What is important here is that the intensity of relations among particular participants of the network may be different. Sometimes an assumption is made that the entities should maintain their organisational and legal independence and that the relations of exchange are of voluntary character. In other events entities seem to partially resign from their own autonomy for the benefit of the other organisations or they coordinate activities on the basis of cooperation of entities in a defined area "inside an organisation". And finally, in certain conditions one may assume interdependence of entities; making decisions together by entities within the set area of cooperation, repeatability of relations among entities and keeping such relations in a longer or non-defined time horizon for the purpose of the implementation of joint strategic ideas. However, each time inter-organisational relations take place among organisations characterised by convergence of a certain type. The convergence may be understood as similar or identical domain of the organisations' activities, resources or infrastructure used by the organisations or the manner of operation. The occurrence of convergence among organisations understood as mentioned above is defined in the literature as strategic interdependence (Góra 2008, p. 13).

The other features of a networking organisation include (Góra 2008, p. 13):

- keeping an organisational and legal independence of entities, entering the exchange relations on a voluntary basis, discreet character of the relations, basing relations among entities on market transactions, coordination of entities' activities based on rivalry and negotiations (for the networking organisation as a market),

- independence of activity of a networking organisation (whose properties and strategy differ from the properties and strategies of the entities creating it); partial resignation of entities from their autonomy for the benefit of the other entities, coordination of activities based on cooperation of entities within a defined area "inside the organisation, mutual adaptation of entities based on the allotment of work and fulfilment of particular functions - interdependence of entities; making decisions together by entities in the set area of cooperation, repeatability of relations among entities and keeping such relations in a longer or non-defined time horizon for the purpose of the implementation of joint strategic ideas (for a network as an organisation),

- free access of each entity to information on the other entities (for a network as a social group).

K. Łobos (2000) distinguishes two types of networks: non-symmetrical and symmetrical: the former ones are dominated by the central entity, while in the 
latter type a central link is missing. A centre of power may be a permanent central company whose reputation attracts the other partners or key, distinguished competences (Mikuła 2006, p. 78). K. Perechuda defines the role of the above-mentioned central company as a "technological guardian, mother of invention, rationalisation and innovativeness, coordinator of projects, monitor of implementations and improvements, navigator in the area of technological competition, setter in the scope of flows of resources, creator of image of the networking enterprise, archivist of information and knowledge, generator and owner of basic processes (Perechuda 2004, pp. 217-218). It organises the network, defines its structure (defines the role of each partner and its relations and connections with the other members of the network), defines objectives of the network and manners of accomplishing the objectives, builds long-term cooperation among network members based on mutual confidence. Apart from that, the central company introduces a motivation system providing for a defined distribution of benefits for all partners (Tubielewicz 2013). It is also a unit designated by the central company that may become an integrator of this kind and fulfil the role of the broker (the existing unit or a team designated specially for this purpose), provided that "(...) the existence of the broker does not mean a necessity to limit the autonomy of networking partners. Each partner has the same opportunities as regards undertaking initiatives" (Mikuła 2006, p. 79). Coordination may be also assured on the basis of joint arrangements made by participants of the network or by means of establishing a separate entity representing the interest of the whole (Mikuła 2006).

\section{From partnership-based controlling to controlling in networking organisations (networking controlling)}

The literature does not provide any hints as regards the way of defining controlling dedicated to networking organisations. However, what should be taken into account is that the concept of controlling, characterised by dynamism and reacting to changes occurring in the economic practice, has undergone changes, both of revolutionary and evolutionary character. For example, the very specialisation of controlling, perception of possibilities and (or rather most of all) the necessity of development of various controlling types are undoubtedly a revolution in the concept in question. The shaping of solutions related to particular controlling types is a natural consequence of the specialisation mentioned above, thus, it is a change of the evolutionary nature. In view of the above, while assessing from this perspective the development 
of controlling for networking organisations, one might look for roots of the networking controlling in the concepts of partnership-based controlling or even strategic controlling.

Taking into account the long-term assurance of the existence of an enterprise as a whole, strategic controlling "interprets the present condition from the perspective of the future, looks for long-term effects, defines considerable deviations of the obtained results from the plan, (...) focuses on research of the external factors, (...) reacts to changes inside an organisation (Fjałkowska 2000, p. 25). This is how it stresses the relations of one enterprise with the surroundings (which complies with the very idea of networking controlling), but the surroundings are taken into account only as regards meeting the objectives of the given enterprise in which the concept of strategic controlling is implemented. Partnership-based controlling is a kind of extension of this concept. It is defined as a method aimed to support management, consisting in the ongoing coordination of establishing and maintaining multilateral relations of the enterprise with the surroundings, co-participation in these processes, as well as systematic supervision over and monitoring of the correctness of the course of the processes (Bieńkowska, Kral, Zabłocka-Kluczka 2004, pp. 4355). This approach does not change the perception towards management of relations among partners, in the management centre there is still a particular enterprise and the effectiveness of cooperation with partners is evaluated from the perspective of this enterprise.

In the context of the above one should assume that controlling dedicated to networking organisations will put the network of cooperation in the centre of interest. Thus, it will support network management by focusing on multilateral relations among all partners composing a networking organisation rather than on bilateral relations between a particular entity and its surroundings. Analogously to the definition of controlling and taking into account the issue of networking organisation, the concept of networking controlling will be understood as a method aimed to support management of inter-organisational relations, consisting in coordination of the activity of the network as a whole (in particular on the strategic level) and maintenance of multilateral relations among entities composing the organisation (taking into account in particular the construction of the IT system among entities), co-participation in these processes and supervision over and monitoring of correctness of their course on a regular basis. The purpose of controlling understood in this way is to support achievement the strategic intention arranged by the organisations connected by the network of cooperation. Pursuant to this concept, all participants (partners) 
should strive together to achieve joint objectives, and at the same time, or rather thanks to this, their own objectives.

Thus, analogously to controlling as a general concept and in particular to partnership-based controlling (Bieńkowska, Kral, Zabłocka-Kluczka 2004, pp. 43-55), networking controlling may be characterised as follows (own studies):

- goal- and future-orientation, reflected in the strive to assure the existence of the network of cooperation and to accomplish its strategic objective arranged by the organisations composing the network,

- bottle-neck orientation, meaning a necessity to identify and eliminate or improve the weakest links of the network of cooperation or the weakest relations among them,

- separation of centres of responsibility (constituting particular links of cooperation or relations of an enterprise with particular partners), being the basis of the evaluation of the effectiveness of the operation of particular networking partners, co-contributing to the effectiveness of the entire network,

- separation of positions of controllers, responsible for identification and interpretation of signals on the functioning of a network of cooperation and changes in its surroundings, and for effective reaction to such signals,

- orientation to value added generated in the processes of creation, development and maintenance of connections among organisations inside the network of cooperation and development of instruments for measurement of this value,

- orientation to relations of the network of cooperation with the surroundings, i.e. in particular with organisations not composing the given network of cooperation or other networking organisations.

\section{Solutions of controlling in networking organisations (networking controlling)}

There are three aspects that should be taken into account when developing solutions of networking controlling: the functional aspect (functions and tasks of networking controlling), the organisational aspect (controllers and centres of responsibility) and the instrumental aspect (tools used during the performance of tasks of networking controlling).

Functional solutions are the ones that should be considered as primary solutions as compared with the two other groups and as ones that strongly determine the other solutions' shaping. In the context of the principles of the organisation and functioning of the network of cooperation and as regards the possibilities of controlling it seems that it is possible to separate three groups of issues that 
might become the areas of interests of networking controlling. They include:

- development of vision and strategy of cooperation, taking into account the future conditions in which it will function,

- activity of the network as a whole and maintaining multilateral relations among members of the network of cooperation,

- assurance of an efficient system of communication among all members of the network of cooperation.

On this basis it is possible to distinguish the three main directions of activities of networking controlling:

- co-participation in the development of strategic ideas of the network of cooperation, including in particular in the scope of arranging the objective of the network of cooperation,

- coordination of the activity of the network of cooperation, supervision over and monitoring of both relations among participants of the network and use of resources made available as part of the network of cooperation; if necessary, it also includes co-participation in the management process,

- construction and maintenance of the system of communication among participants of the network, i.e. in particular the IT system based on the selection of IT methods and tools, allowing to gather information and reporting the results of the work of the network, including its effectiveness and effectiveness of the resources used as part of the network.

\section{Co-participation in the development of the strategic idea of the network of cooperation}

The basic reason for establishment of networks of cooperation is the ability to perceive benefits resulting from the connection of resources and unique configurations of key competences and knowledge at the disposal of the organisations that have been operating on their own so far. As regards gaining these benefits, the basis condition is "the same objective", leading to the adoption by organisations of an integrated strategy of operation and cooperation (supporting one another in these activities), connected by their strive for the achievement of the common objective. Notwithstanding the degree of limitation of the autonomy of entities creating the network, it is the managing parties that are responsible for the development of the objective complying with the objectives of particular partners (and development of the common vision of the future of the network). However, controllers may co-participate in the process at the stage of the construction (including establishing the objectives) of the network by means of performing particular substantive tasks, such as: 
- searching for, recognising and establishing possible objectives of the network of cooperation referring to all external conditions of the network as well as to the objectives of particular partners, identification of discrepancies between the hitherto objectives of particular partners and the objectives of the network and indication of necessary areas of adaptation,

- co-participation in the formulation of the strategic idea of the network by making efforts for the adopted procedures to comply with the objective of the entire network and the objectives of the particular partners,

- construction of the system of indicators allowing to monitor the effectiveness of the functioning of the network, including in particular allowing to assess the accomplishment of the objectives of the network of cooperation as a whole and, if required, the objectives of particular partners,

and at the stage of the functioning of the network, e.g. by means of verification of the validity of the adopted objectives in the network in the context of the changing surroundings, supervision over the accomplishment of the objectives and definition of manners of operation and procedures to be complied with if any deviations from the adopted assumptions are found.

\section{Coordination of the activity of the network of cooperation}

From the classic perspective, coordination constitutes the basic function of controlling. As regards networking controlling, the coordination function also seems to be of particular significance because of a necessity to arrange and harmonise the activities of particular entities composing the network. On the one hand, the need to coordinate stems from considerable variability of the network configuration (in particular in the event of dispersed networks and networks of a low degree of formalisation of relations among partners), on the other hand, it stems from the necessity to take into account various interdependences (personal, objective and temporal) among particular entities composing the network, and a lack of the coordination may result not only in reduction in efficiency of the operation of the networking organisation, but also, in the extreme case, it may completely prevent the network from accomplishing its objectives. Thus, coordination includes the process of integration, or, to be more precise, of arranging objectives, tasks and actions undertaken by different participants of the network of cooperation and its surroundings, but also the principles of making resources available, in particular in the scope of planning and control of the performance of joint undertakings (including allotment and use of resources) and managing their performance, both at the stage of the creation of the network and at the stage of its later functioning. However, 
controllers, being the performers of the tasks of networking controlling, do not relieve managers in the performance of coordination activities, but they only support activities carried out by managers, while the scope of their coparticipation and selection of the used mechanisms of coordination seems, on the one hand, to depend on the structure of the network, its size and variability as well as the degree of formality of the relations among partners of the network, on the other hand, though, it is strongly connected with the adopted philosophy of the shaping of organisational and instrumental solutions of the controlling in networking organisations.

Because of the diversity and variability of networking connections and their interdependence (changes in one area usually result in changes in the other areas), networking organisations have to use diverse mechanisms of coordination.

As regards symmetrical networks, with no strong integrator (i.e. a centre of power able to make many independent entities cooperating as part of the network to carry out a decision, which would undoubtedly lead to reduction in the effectiveness of the operation of the network of cooperation), the mechanism of coordination in the form of personal direct supervision loses significance. Here coordination may be assured for example by means of making arrangements among interested participants of the network, but if interests of all participants were taken into account, the threat of suboptimation and reduction in the effectiveness of the operation of the networking organisation as a whole becomes real. In particular, in this event a large part of coordination tasks should be taken on by controllers (placed in particular units of the network), constituting staff connecting the links (partners) of the network.

As regards non-symmetrical networks, dominated by a central entity, the coordination through direct supervision exercised by a dominant entity (or in many cases a coordinating entity established specially for this purpose) seems to be possible, but it should be limited to solving problems of strategic significance to the network (e.g. regarding identification of the objectives of the network of cooperation or determining means of performance of such objectives). But here one should make effort for the cooperation not to transform into imposing conditions, limiting a possibility of undertaking grass-roots initiatives. Making arrangements and mutual adaptation to the interests of interested participants of the network (the horizontal coordination mechanism) is a very important mechanism of coordination also in such a network. In non-symmetrical networks a controlling unit should be in an organisation acting as the leader or coordinator of the network, while tasks of controllers should be connected with sharing information (making information available and codification of the 
manners of communication in the network) and synchronisation of primary processes carried out as part of the network of cooperation.

Regardless of the manner of configuration of the network of cooperation, as regards the supervision over and monitoring of the performance of operational tasks of the networks, more significance should be attributed to the mechanisms of cooperation that are based on standardisation of qualifications, input/ output, results, or, eventually, the course of processes with the use of the adopted procedures (rules and procedures adopted in advance and included in programmes and plans of action). The more mature solutions in the scope of communication among partners of the cooperation are applied, the greater will be the intensity of their use.

\section{Construction of the system of communication among participants of the network of cooperation}

What plays a key role in the coordination process is the communication among participants of the network (Tubielewicz 2013). Participants have different information, which is usually distributed non-symmetrically, and it is only the unique combination of such items of information that leads to reaching the synergy effect and accomplishment of the objectives of the network of cooperation. It is the reason why sharing important, accurate and up-to-date information, meeting the ongoing and future needs of the participants of the network and necessary for the cooperation (in particular with regard to the performance of the basic objectives of the cooperation) is a factor determining the efficiency of the operation of the entire networking organisation. Organisations composing the network may choose from a wide range of potential means of communication, from traditional means of communication, such as post, phone, fax, to state-of-the-art IT and communication systems allowing inter alia to search for information according to strictly defined criteria, provision of information on strictly defined time (timing), monitoring of the flow of information, development and management of databases. What raises no doubts is that the contemporary conditions of the functioning of enterprises, including networking organisations, require establishment of a platform for communication and cooperation with the other partners on the basis of the IT standard. "Thus, the fundamental component of the architecture of the contemporary networking organisation is its IT system with a defined structure of components and their interrelations as well as principles and guidelines related to the design and implementation" (Tubielewicz 2013). From the perspective of controlling, the system should allow to monitor the activity of both the network as a whole and 
of its particular participants (including in particular gathering information and reporting the results of the work of the network, its effectiveness and the effectiveness of the used resources shared within the network), to verify whether the adopted coordination mechanisms provide for the accomplishment of objectives and whether the obtained results meet the expectations of the creators and participants of the network. The controllers' task is not only to supervise the correctness of the functioning of the system, but most of all to co-participate in the process of shaping of the system.

Organisational solutions of controlling in networking organisations are connected with the design of relevant structures within which tasks of the controlling will be carried out. The controller is the key link of such structures. So far the literature has not presented any guidelines in the scope of including controllers in the structure of networking organisations and assigning them with a scope of duties, powers and responsibility. What is of great significance here is that the process should take into account both solutions related to the specificity of the functioning of the networking organisation as a whole and the ones related to controlling in general, which may create many dilemmas. It is important to separate the existing roles in the networking organisation (integrator, network coordinator) from the tasks assigned to the controller, but one may assume that in case of some configurations/types of networking organisations these tasks may partially penetrate each other to a certain extent. At the same time it is beyond all doubt that internal clients of controllers in networking organisations will be both particular units composing the network and dominant entities (integrator, network coordinator). Some tasks assigned to controllers in networking organisations have already been indicated. Furthermore, a controller may fulfil the role of an entity reviewing the practices used by particular partners participants of the network and striving for the unification of such practices as part of the common standards adopted by participants of the network, advising in the scope of improving tasks in this field. A controller may also monitor the activity of partners (in particular the results and maintaining statistics related to them, as well as prepare reports for the needs of participants of the network and external entities, inform of the obtained results of the operation of the network and the threat to the accomplishment of its basic objectives). So far the scope of the variability of the controller's tasks depending on the configuration of the network and variability of the dynamism of connections among partners has not been the subject of empirical verification, but as the concept develops, it will certainly become the subject of further research.

The second organisational dimension of networking controlling regards the 
possibility of separation in the networking organisation of controlling centres of responsibility. To some extent this solution is self-evident. Since each entity composing the network is a separate legal person and is fully independent (the scope of the freedom of its operation is limited only by the obligations undertaken by it voluntarily), each organisation being an element of the network may be considered as the investment centre. What should be emphasised here is that the centres of responsibility separated in this way are not typical (within the strict meaning of controlling) centres of management, since on the other hand the responsibility of their managers relates to economic results of the activity of such centres, but it is also extended to the accomplishment of objectives and results of the entire network.

The design of instrumental solutions of controlling in networking organisations comes down to indicating and adopting instruments that might be useful for the assessment of effectiveness of the functioning of the network of cooperation and particular elements of the network. Networking controlling does not have its own new instruments, but it uses the achievements of the other disciplines by transforming and adapting the tools offered by such disciplines to its own needs. As regards the assessment of the effectiveness of the functioning of particular elements of the network, there is no need to transform the existing solutions, since all instruments and methods of the financial analysis are valid here. It is a challenge to measure the synergy effect worked out as part of the entire network and effectiveness of the use of resources shared as part of the network. What seems to be possible for the accomplishment of this objective is to use the achievement measurement system reflecting in a networking organisation the process of reaching the assessment of effectiveness and efficiency of the organisation's operation. The construction of the achievement process system is not possible without selection of relevant indicators corresponding to the adopted objectives of both the networking organisation as a whole and particular centres of responsibility, i.e. organisations composing the networking organisation. It is controllers that should deal with their identification and verification.

\section{Summary}

The issue of the functioning of a networking organisation is cooperation of the organisations composing the network, sharing knowledge, skills, competences, sharing unique resources and orientation to achievement of a common objective. Networking connections must be flexible, since their configuration is subject to frequent changes, and they must be certain and stable at the same time. This 
form of cooperation requires considerable confidence and efficient mechanisms of coordination.

It seems that a method supporting effective organisation management may be a specific type of controlling, oriented to support of the management of relations among organisations, and consisting in coordination of the operation of the network as a whole and maintaining multilateral relations among entities composing the network. It facilitates, with the use of the latest achievements in the scope of telecommunication technologies, supervision over and monitoring of the correctness of their course, support of the processes related to the measurement of the effectiveness of the entire network and particular elements of the network as well as strong orientation to elimination of deviations from the performance of the arranged objective of the network.

\section{Summary}

\section{Controlling in networking organisations - the concept and assumptions}

The article contains the characterisation of the issue and features of a networking organisation. In the context of a specific manner of cooperation among organisations-partners in the network there has been indicated a great need for coordination of activities of particular entities for the purpose of meeting the arranged objectives and controlling has been proposed as a method supporting effective networking organisation management. The article presents the evolution of the concept of controlling from strategic controlling, to partnership-based controlling towards controlling in networking organisations. The concept and tasks of controlling in networking organisations (networking controlling) have been defined. There has been presented an outline or functional, organisational and instrumental solutions.

Key words: controlling, networking organisation, network of cooperation.

\section{Streszczenie}

Controlling w organizacjach sieciowych - koncepcja i założenia $W$ artykule scharakteryzowano istotę $i$ cechy organizacji sieciowej. W kontekście specyficznego sposobu współpracy miedzy organizacjami - partnerami w sieci wskazano dużą potrzebę koordynacji działań poszczególnych podmiotów w celu realizacji 
współuzgodnionych zamierzeń i zaproponowano controlling jako metodę wspierającą sprawne zarządzanie organizacją sieciową. Przedstawiono ewolucję koncepcji controllingu od controllingu strategicznego, przez controlling partnerski w stronę controllingu $\mathrm{w}$ organizacjach sieciowych. Zdefiniowano pojęcie i zadania controllingu $\mathrm{w}$ organizacjach sieciowych (controllingu sieciowego). Nakreślono zarys jego rozwiązań funkcjonalnych, organizacyjnych i instrumentalnych.

\section{Słowa}

kluczowe: controlling, organizacja sieciowa, sieć wspótpracy.

\section{References}

1. Bieńkowska A., Kral Z., Zabłocka-Kluczka A. (2004), Controlling partnerski w: E. Nowak (red.), Rachunkowość zarzadcza i controlling w warunkach integracji z Unia Europejska, Prace Naukowe Akademii Ekonomicznej im. Oskara Langego we Wrocławiu; nr 1090, Wyd. Uniwersytetu Ekonomicznego we Wrocławiu, Wrocław.

2. Fjałkowska D. (2000), Controlling strategiczny - awangarda czy praktyka?, "Controlling i Rachunkowość Zarządcza", nr 4.

3. Góra J. (2008), Dynamika klastra- zarys teorii i metodyka badań, Wyd. WSH, Wrocław.

4. Łobos K. (2000), Organizacja sieciowa, w: K. Perechuda (red.), Zarzadzanie przedsiębiorstwem przyszłości, Agencja Wydawnicza „Placet”, Warszawa.

5. Mikuła B. (2006), Organizacje oparte na wiedzy, Wyd. Akademii Ekonomicznej w Krakowie, Kraków.

6. Perechuda K. (2004), Dyfuzja wiedzy w przedsiębiorstwie sieciowym: wizualizacja i kompozycja, Wyd. Akademii Ekonomicznej we Wrocławiu, Wrocław.

7. Skrzyniarz P. (2002), Indyholidyna - pryzmat controllera, "Controlling i Rachunkowość Zarządcza", nr 3.

8. Strategor (1995), Zarządzanie firma. Strategie, struktury, decyzje, tożsamość, PWE, Warszawa.

9. Tubielewicz A. (2013) Koncepcja tworzenia organizacji sieciowej, w: R. Knosala (red.), Innowacje w Zarzadzaniu i Inżynierii Produkcji, Oficyna Wydawnicza Polskiego Towarzystwa Zarządzania Produkcją, Opole. 